\title{
STUDI TINGKAT KEMISKINAN RUMAH TANGGA NELAYAN DI KECAMATAN BATULAYAR KABUPATEN LOMBOK BARAT
}

\author{
STUDY OF FISHERIES HOUSEHOLD POVERTY LEVEL \\ IN BATULAYAR DISTRICT, WEST LOMBOK REGENCY
}

\author{
Novita Angriani, Wuryantoro, Amiruddin \\ Program Studi Agribisnis Fakultas Pertanian UNRAM
}

\begin{abstract}
ABSTRAK
Rendahnya penghasilan nelayan tradisional merupakan masalah yang sudah lama, namun masalah ini masih belum dapat diselesaikan hingga sekarang, karena terlalu kompleks. Hal ini tidak hanya berkaitan dengan sosioekonomi, namun berkait pula dengan lingkungan dan teknologi. Penelitian bertujuan untuk menganlisis pendapatan rumah tangga nelayan dan kontribusi pendapatan yang bersumber dari usaha tanggkapan ikan terhadap pendapatan rumah tangga nelayan, serta menganalisis tingkat kesejahteraan rumahtangga nelayan di Kecamatan Batulayar Kabupaten Lombok Barat. Metode yang digunakan dalam penelitian ini adalah deskriptif, dengan mewawancarai responden sebanyak 35 responden. Data dianalisis secara kuantitatif dan kualitatif selanjutnya dideskripsikan. Hasil penelitian menunjukkan bahwa ratarata pendapatan rumah tangga nelayan di Kecamatan Batulayar selama sebulan sebesar Rp 1.625.983, kontribusi pendapatan dari usaha penangkapan ikan sebesar 64,65\%. Tingkat kemiskinan rumahtangga nelayan di Kecamatan Batulayar Kabupaten Lombok Barat menurut BPS, termasuk kategori miskin namun menurut Bank Dunia dikategorikan tidak miskin.
\end{abstract}

Kata kunci : Pendapatan nelayan, kesejahteraan, rumah tangga nelayan.

\begin{abstract}
The low income of traditional fishermen is a long-standing problem, but this problem still cannot be resolved until now, because it is too complex. This is not only related to socioeconomic problems, but also related to the environment and technologists. The research aims to analyze fishermen's household income and the contribution of income derived from fish farming to the income of fishermen households, and to analyze the welfare level of fishermen households in Batulayar District, West Lombok Regency. The study applied descriptive methods, while collecting data were done with survey techniques, by interviewing 35 respondent. Collected data were analyzed using quantitative and qualitative analysis and was subsequently described. The results of the study show the average income of fisherman households in Batulayar District for a month was Rp. 1,625,983, with the contribution of income from fishing to fishermen's household income by $64.65 \%$. The welfare level of fishermen households in Batulayar District, West Lombok Regency according to BPS is categorized as poor but according to the World Bank it is categorized as not poor
\end{abstract}

Key words: Fisherman's income, welfare, household fishermen 


\section{PENDAHULUAN}

Nelayan tradisional pada umumnya hidup di bawah garis kemiskinan. Hal ini disebabkan ciri-ciri yang melekat pada nelayan yaitu suatu kondisi yang subsisten, dengan modal yang kecil, teknologi yang digunakan dan kemampuan atau skill serta perilaku yang tradisional baik dari segi keterampilan, psikologi dan mentalitas (Susilowati, 1991). Rendahnya penghasilan nelayan tradisional merupakan masalah yang sudah lama, namun masalah ini masih belum dapat diselesaikan hingga sekarang, karena terlalu kompleks. Hal ini tidak hanya berkaitan dengan sosioekonomi, namun berkait pula dengan lingkungan dan teknologi.

Kecamatan Batulayar merupakan salah satu dari sepuluh kecamatan yang ada di Kabupaten Lombok Barat dengan jumlah penduduk 54.203 jiwa, dengan luas wilayah $34.11 \mathrm{~km}^{2}$ dan kepadatan penduduk $1.589 \mathrm{jiwa} / \mathrm{km}^{2}$. Kecamatan Batulayar sebagian penduduknya berada di wilayah pesisir yang secara umum masyarakat pesisir di wilayah ini menggantungkan hidupnya sebagai nelayan. Dalam kenyataannya sangat bisa dan kemungkinan berada di bawah garis kemiskinan. Persosalan pendapatan nelayan tergantung dari produksi yang didapat, modal yang masih terbatas dan sebagainya. Berdasarkan uraian sebelumnya yang menjadi permasalahan dalam penelitian ini adalah: (1) Seberapa besar pendapatan rumahtangga nelayan di Kecamatan Batulayar Kabupaten Lombok Barat?; (2) Bagaimana kontribusi pendapatan yang bersumber dari nelayan dalam pendapatan rumahtangga nelayan di Kecamatan Batulayar Kabupaten Lombok Barat; (3) Bagaimana tingkat kemiskinan rumahtangga nelayan di Kecamatan Batulayar Kabupaten Lombok Barat?.

Penelitian bertujuan untuk: (1) Mengetahui pendapatan rumahtangga nelayan di Kecamatan Batulayar Kabupaten Lombok Barat. (2) Mengetahui kontribusi pendapatan yang bersumber dari nelayan dalam pendapatan rumahtangga nelayan di Kecamatan Batulayar Kabupaten Lombok Barat. (3) Mengetahui tingkat kemiskinan rumahtangga nelayan di Kecamatan Batulayar Kabupaten Lombok Barat.

\section{METODE PENELITIAN}

Metode yang digunakan dalam penelitian ini adalah deskriptif, sedangkan penentuan daerah sampel secara purposive sampling, penentuan jumlah responden sebanyak 35 orang. Penentuan jumlah responden pada masing-masing desa sampel secara proportional random sampling. Data dianalisis secara deskriptif. Jenis data yang digunakan adalah data kuantitatif dan data kualitatif. Sumber data yang digunakan adalah data primer dan data sekunder.

Data yang terkumpul kemudian dianalisis dengan menggunakan analisis deskriptif yaitu data disusun, diolah, disajikan dan ditarik kesimpulan. Untuk mengetahui pendapatan nelayan digunakan analisis biaya dan penerimaan, dengan rumus (Soekartawi, 1998):

$\mathrm{I}=\mathrm{TR}-\mathrm{TC}$

Keterangan :

I = Pendapatan atau Income (keuntungan)

$\mathrm{TR}=$ Total Revenue atau Total Penerimaan

$\mathrm{TC}=$ Total Cost atau Total Biaya 
Untuk mengetahui pendapatan rumah tangga nelayan dilakukan dengan menjumlahkan semua pendapatan yang di peroleh rumah tangga nelayan selama satu tahun baik sebagian dari nelayan maupun dari usaha bukan dari nelayan (Suproyo, 2009):

$\mathrm{PK}=\mathrm{PN}+\mathrm{U}$

Keterangan :

PK $=$ Pendapatan Rumah Tangga Nelayan

$\mathrm{PN}=$ Pendapatan dari Kegiatan Nelayan

$\mathrm{U}=$ Pendapatan dari Bukan Kegiatan Nelayan

Untuk mengetahui pendapatan per kapita rumah tangga nelayan dilakukan dengan membagi pendapatan rumah tangga nelayan dengan jumlah anggota rumah tangga (Bank Dunia, 2009):

$\mathrm{PK}=\frac{\mathrm{PK}}{\sum \mathrm{AK}}$

Keterangan :

PK = Pendapatan per Kapita

PK = Pendapatan Rumahtangga Nelayan

$\sum$ AK $=$ Jumlah Anggota Keluarga

Selanjutnya untuk mengetahui kontribusi pendapatan yang bersumber dari usaha penangkapan ikan terhadapa pendapatan nelayan digunakan analisis sebagai berikut:

$\mathrm{K}=\frac{\mathrm{I}}{\mathrm{I}_{\mathrm{f}}+\mathrm{I}_{\mathrm{m}}+\mathrm{I}_{\mathrm{O}+\mathrm{I}}} \times 100$

Keterangan :

$\mathrm{K}=$ Kontribusi nelayan (satuan \%)

$\mathrm{I}=$ Pendapatan nelayan $(\mathrm{Rp} / \mathrm{Tahun})$

$\mathrm{I}_{\mathrm{f}}=$ Pendapatan istri (satuan Rp)

$\mathrm{I}_{\mathrm{m}}=$ Pendapatan suami (satuan $\mathrm{Rp}$ )

$\mathrm{I}_{\mathrm{O}}=$ Pendapatan anak (satuan Rp)

Untuk mengetahui tingkat kesejahteraan/kemiskinan rumahtangga nelayan diukur dengan menggunakan kriteria kemiskinan menurut BPS dan Bank Dunia sebagai berikut, yaitu : menurut BPS (2017):

1. Tidak Miskin, adalah mereka yang pendapatan $>$ Rp 401.220 per kapita per bulan.

2. Miskin adalah mereka yang pengeluaran $\leq \mathrm{Rp} 401.220$ per kapita per bulan.

Menurut Bank Dunia:

1. Tidak Miskin, adalah mereka yang berpendapatan per hari > US\$ 1

2. Miskin, adalah mereka yang berpendapatan per hari $<$ US\$ 1 


\section{HASIL DAN PEMBAHASAN}

\section{Pendapatan Rumah Tangga Nelayan}

Pendapatan rumah tangga nelayan yang dimaksud dalam penelitian ini adalah pendapatan yang bersumber dari seluruh keluarga nelayan meliputi suami, istri dan anak dari kegiatan sebagai nelayan dan luar nelayan. Beranekaragamnya pola usaha yamg ditekuni rumah tangga nelayan pada hakekatnya memiliki tujuan yang sama yaitu memperoleh pendapatan guna memenuhi kebutuhan hidup nelayan beserta keluarganya. Sumber pendapatan rumah tangga nelayan dapat diuraiannya sebagai berikut.

Tabel 1. Rata-rata Pendapatan Rumah Tangga Nelayan di Kecamatan Batulayar Tahun 2016

\begin{tabular}{|l|l|c|c|}
\hline No & \multicolumn{1}{|c|}{ Uraian } & $\begin{array}{c}\text { Rata-rata } \\
(\mathrm{Rp} / \mathrm{Bln})\end{array}$ & Persentase (\%) \\
\hline 1 & Pendapatan dari kegiatan nelayan : & 1.051 .239 & 64,65 \\
\hline 2 & Pendapatan luar nelayan : & & \\
\hline & - Suami (Buruh bangunan) & 339.429 & 20,88 \\
\hline & - Istri (Pedagang) & 201.029 & 12,36 \\
\hline & - Anak (Karyawan) & 34.286 & 2,11 \\
\hline & Total Pendapatan & $\mathbf{1 . 6 2 5 . 9 8 3}$ & $\mathbf{1 0 0}$ \\
\hline
\end{tabular}

Sumber: Data Primer Diolah, Tahun 2017

Berdasarkan Tabel $1 \mathrm{di}$ atas menunjukkan bahwa rata-rata total pendapatan rumah tangga nelayan di Kecamatan Batulayar sebesar Rp 1.625.983/bulan. Lebih dari separuh $(64,65 \%)$ dari total pendapatan rumah tangga merupakan kontribusi dari kegiatannya sebagai nelayan.

Kegiatan dari luar nelayan mampu memberikan tambahan pendapatan rata-rata sebesar Rp 574.744 atau 35,35\% dari total pendapatan rumah tangga setiap bulan. Secara nominal, pendapatan yang diperoleh dari kegiatan ini relatif rendah sehingga anggota rumah tangga nelayan harus mencari pekerjaan lain seperti menjadi buruh bangunan dan berdagang untuk menambah pendapatan guna memenuhi kebutuhan hidup sehari-hari. Angka pendapatan luar nelayan ini relatif rendah, hal ini disebabkan hanya sebagian kecil yaitu sebanyak 20 orang (16.81\%) dari total jumlah anggota rumah tangga sebesar 119 orang yang terlibat dalam kegiatan produktif di luar sebagai nelayan.

\section{Pendapatan sebagai Nelayan}

Sumber pendapatan rumah tangga nelayan yang diperoleh dari kegiatan sebagai nelayan adalah kegiatan sebagai nelayan yang merupakan mata pencaharian utama bagi masyarakat pesisir di Kecamatan Batulayar. Besar kecilnya pendapatan rumah tangga nelayan dipengaruhi oleh cuaca atau musim (musim barat dan musim timur) untuk melakukan kegiatan melaut.

\section{a. Biaya Produksi}

Dalam penelitian ini total biaya produksi adalah seluruh biaya yang dikeluarkan oleh nelayan pada usaha penangkapan ikan selama sebulan. Jenis biaya produksi yang dikeluarkan dalam usaha penangkapan ikan dapat dibedakan menjadi 
dua yaitu biaya variabel dan biaya tetap. Besarnya biaya yang dikeluarkan oleh rumah tangga nelayan dari kegiatan melaut selama sebulan di Kecamatan Batulayar Kabupaten Lombok Barat, Tahun 2016 disajikan pada Tabel 2 berikut.

Tabel 2. Rata-Rata Besarnya Biaya yang dikeluarkan Nelayan dari Kegiatan Melaut Selama Sebulan Tahun 2017

\begin{tabular}{|l|l|r|r|}
\hline No & \multicolumn{1}{|c|}{ Uraian } & $\begin{array}{r}\text { Musim Timur } \\
\text { (Maret-Agustus) }\end{array}$ & \multicolumn{1}{|c|}{$\begin{array}{c}\text { Musim Barat } \\
\text { (September- } \\
\text { Februari) }\end{array}$} \\
\hline 1 & Biaya Variabel (Rp) & & 45.828 \\
\hline & a. Bensin & 407.200 & 1.192 \\
\hline & b. Oli & 9.056 & 47.020 \\
\hline & Jumlah & 416.256 & 56.637 \\
\hline & Biaya Tetap (Rp) & & 31.619 \\
\hline & a. Penyusutan alat & 56.637 & 20.500 \\
\hline & - Perahu & 31.619 & 2.361 \\
\hline & - Mesin & 20.500 & 702 \\
\hline & - Jaring & 2.361 & 570 \\
\hline & - Pancing & 702 & 476 \\
\hline & - Dayung & 570 & 112.865 \\
\hline & - Ember & 476 & $\mathbf{1 5 9 . 8 8 5}$ \\
\hline & b. Biaya Pemeliharaan & 112.865 & $\mathbf{5 2 9 . 1 2 1}$ \\
\hline
\end{tabular}

Sumber: Data Primer Diolah (2017)

Biaya variabel yang dikeluarkan nelayan dari usaha penangkapan ikan di Kecamatan Batulayar terdiri dari pembelian bensin dan oli. Pada Tabel 2 diketahui rata-rata biaya variabel dari usaha penangkapan ikan selama sebulan pada musim timur sebesar Rp 416.256 dan Rp 47.020 pada musim barat. Dilihat dari musim penangkapan terdapat perbedaan antara biaya variabel yang dikeluarkan oleh nelayan, dimana pada musim timur lebih besar dibandingkan pada musim barat. Adanya perbedaan biaya variabel tersebut disebabkan karena pada musim timur nelayan lebih sering melaut dari pada musim barat. Hasil penelitian menunjukkan bahwa nelayan pergi melaut dalam seminggu antara 6-7 kali pada musim timur, sedangkan pada musim barat berkisar pergi melaut dalam seminggu antara 1-2 kali.

Hasil penelitian ini menunjukkan bahwa, rata-rata biaya produksi yang dikeluarkan oleh rumah tangga nelayan selama sebulan pada musim timur sebesar Rp 529.121 dan pada musim barat sebesar Rp 159.885. Biaya tersebut terdiri atas biaya variabel (bensin, oli), dan biaya tetap (penyusutan alat dan biaya pemeliharaan alat).

\section{b. Produksi dan Nilai Produksi}

Produksi dimaksud dalam penelitian ini adalah ikan yang bernilai ekonomi dari hasil tangkapan nelayan dengan tujuan untuk memperoleh pendapatan memenuhi kebutuhankeluarga. Produksi dan nilai produksi pada musim timur dan musim barat disajikan pada Tabel 3 berikut. 
Tabel 3. Rata- Rata Produksi, Harga dan Nilai Produksi Nelayan Selama Sebulan Tahun 2017

\begin{tabular}{|l|r|r|}
\hline \multicolumn{1}{|c|}{ Uraian } & Musim Timur & \multicolumn{1}{c|}{ Musim Barat } \\
\hline 1. Produksi (Kg) & 124 & 4 \\
2. Harga (Rp/Kg) & 19.519 & 79.271 \\
3. Nilai Produksi (Rp) & 2.420 .400 & 371.085 \\
\hline
\end{tabular}

Sumber : Data Primer Diolah ( 2017)

Berdasarkan Tabel 3 nilai produksi diperoleh rumah tangga nelayan jauh lebih besar pada musim timur dari pada musim barat, yaitu sebesar Rp 2.420 .400 pada musim timur dan Rp 371.085 pada musim barat. Untuk rata-rata produksi (hasil tangkapan ikan) rumah tangga nelayan jauh lebih besar produksinya pada musim timur dari pada musim barat, yaitu sebesar $124 \mathrm{Kg}$ pada musim timur dan $4 \mathrm{Kg}$ pada musim barat. Sedangkan untuk harga jual jauh lebih tinggi pada musim barat dibandingkan musim timur yaitu sebesar Rp 79.271/Kg, sedangkan pada musim timur sebesar Rp 19.519/Kg.

Berdasarkan hasil penelitian, tingginya harga pada musim barat disebabkan karena pada saat musim barat intensitas melaut dikurangi yang biasanya nelayan pergi melaut sekitar 6-7 kali dalam seminggu, sedangkan pada musim barat sekitar 1-2 kali dalam seminggu. Dengan kondisi ini jumlah tangkapan ikan yang diperoleh sedikit sehingga menyebabkan tingginya harga ikan. Hasil tangkapan ikan yang diperoleh nelayan biasanya dijual di pasar tradisional dan sesekali dijual bakulan ke rumah tetangga.

\section{c. Pendapatan Nelayan}

Pendapatan nelayan di Kecamatan Batulayar dipengaruhi oleh besarnya biaya produksi yang dikeluarkan dan nilai produksi yang dihasilkan. Pendapatan nelayan dari usaha penangkapan ikan dapat diketahui dengan menghitung nilai produksi dikurangi dengan biaya produksi yang telah dikeluarkan. Pendapatan nelayan dari kegiatan melaut selama sebulan pada musim timur dan musim barat di Kecamatan Batulayar Kabupaten Lombok Barat, Tahun 2017 disajikan pada Tabel 4 berikut.

Tabel 4. Analisis Pendapatan Nelayan Selama Sebulan di Kecamatan Batulayar Kabupaten Lombok Barat Tahun 2017

\begin{tabular}{|r|l|r|r|}
\hline No. & \multicolumn{1}{|c|}{ Uraian } & Musim Timur & \multicolumn{1}{c|}{ Musim Barat } \\
\hline 1. & Nilai Produksi (Rp) & 2.420 .400 & 371.085 \\
\hline 2. & Biaya Produksi (Rp) & 529.121 & 159.885 \\
\hline & Pendapatan (Rp) & $\mathbf{1 . 8 9 1 . 2 7 9}$ & $\mathbf{2 1 1 . 2 0 0}$ \\
\hline
\end{tabular}

Sumber : Data Primer Diolah,Tahun 2017

Berdasarkan Tabel 4 di atas, diketahui rata-rata pendapatan pada musim timur lebih tinggi yaitu sebesar Rp 1.891.279/bulan dan pendapatan pada musim barat sebesar Rp 211.200/bulan. Tingginya pendapatan pada musim timur disebabkan oleh tingginya produksi yang diperoleh. Hal ini mengiindikasikan bahwa usaha di sektor perikanan dapat meningkatkan pendapatan rumah tangga nelayan, dan pada akhirnya tingkat kesejahteraan rumah tangga nelayan juga cenderung meningkat. 


\section{Pendapatan dari Luar Usaha Nelayan}

Sumber pendapatan rumah tangga nelayan yang cukup penting di luar pekerjaan pokoknya meliputi usaha kepala keluarga sebagai buruh bangunan dan anggota keluarga (istri dan anak) sebagai pedagang, dan karyawan. Rinciannya disajikan pada Tabel 5 berikut.

Tabel 5. Rata-rata Pendapatan Rumah Tangga Nelayan dari Luar Usaha Nelayan Selama Sebulan di Kecamatan Batulayar Tahun 2017

\begin{tabular}{|l|l|r|r|r|}
\hline \multirow{2}{*}{ No } & \multirow{2}{*}{ Pekerjaan } & \multicolumn{3}{|c|}{ Pendapatan Rumah Tangga dari Luar Nelayan } \\
\cline { 2 - 5 } & & Suami & \multicolumn{1}{|c|}{ Istri } & Anak \\
\hline 1 & Buruh Bangunan & Rp 339.429 & 0 & 0 \\
\hline 2 & Pedagang & 0 & Rp 201.029 & 0 \\
\hline 3 & Karyawan & 0 & 0 & Rp 34.286 \\
\hline \multicolumn{3}{|l|}{ Jumlah } & & Rp 574.744 \\
\hline
\end{tabular}

Sumber: Data Primer Diolah, Tahun 2017

Kegiatan di luar usaha perikanan ini merupakan kegiatan yang dilakukan pada saat waktu luang atau di sela-sela kegiatan sebagai nelayan. Biasanya nelayan melakukan pekerjaan sampingan pada saat musim barat, yaitu pada bulan September sampai dengan Februari. Dari tabel 5 hasil penelitian menunjukkan bahwa pekerjaan sampingan nelayan pada saat tidak melaut yaitu sebagai buruh bangunan dengan ratarata pendapatan suami sebesar Rp 339.429/bulan, sumbangan pendapatan istri sebagai pedagang yaitu sebesarRp 201.029/bulan. Adapula sumbangan pendapatan dari anak sebagai karyawan sebesar Rp 34.286/bulan (dengan dibagi rata-rata 35 responden). Pendapatan ini relatif rendah dari total pendapatan rumah tangga nelayan disebabkan karena hanya sebagian anggota keluarga yang memilih bekerja sampingan sedangkan yang lain memilih tidak bekerja sampingan padahal memiliki kesempatan yang cukup tinggi.

\section{Kontribusi Pendapatan Nelayan}

Kontribusi pendapatan usaha penangkapan ikan terhadap total pendapatan rumah tangga nelayan dapat diketahui dengan membandingkan pendapatan rata-rata rumah tangga nelayan dari usaha penangkapan ikan terhadap total pendapatan rumah tangga dari seluruh sumber pendapatan. Untuk mengetahui besarnya kontribusi yang bersumber dari pendapatan nelayan, maka dapat disajikan pada Tabel 6 berikut.

Tabel 6. Rata-rata Kontribusi Sumber-Sumber Pendapatan Rumah Tangga Nelayan Terhadap Total Pendapatan Rumah Tangga Nelayan di Kecamatan Batulayar Tahun 2017

\begin{tabular}{|r|l|r|r|}
\hline No & \multicolumn{1}{|c|}{ Sumber Pendapatan } & $\begin{array}{c}\text { Pendapatan } \\
(\mathbf{R p} / \mathbf{B} \mathbf{n})\end{array}$ & $\begin{array}{c}\text { Kontribusi } \\
(\mathbf{\%})\end{array}$ \\
\hline 1 & Pendapatan Nelayan & 1.051 .239 & 64,65 \\
\hline 2 & Pendapatan Suami (buruh bangunan) & 339.429 & 20,88 \\
\hline 3 & Pendapatan Istri (pedagang) & 201.029 & 12,36 \\
\hline 4 & Pendapatan Anak (karyawan) & 34.286 & 2,11 \\
\hline & Total Pendapatan & $\mathbf{1 . 6 2 5 . 9 8 3}$ & $\mathbf{1 0 0}$ \\
\hline
\end{tabular}

Sumber: Data Primer Diolah, Tahun 2017 
Berdasarkan hasil penelitian yang dilakukan di Kecamatan Batulayar dapat dilihat pada Tabel 6 secara umum kontribusi pendapatan usaha penangkapan ikan yaitu sebesar Rp 1.051.239/bulan (64,65\%). Ini menunjukkan bahwa kontribusi usaha penangkapan ikan terhadap pendapatan total rumah tangga nelayan berpengaruh cukup besar terhadap pendapatan rumah tangga nelayan.

Faktor-faktor yang menyebabkan semakin ditekuninya usaha penangkapan ikan oleh rumah tangga nelayan yaitu dengan kenyataan bahwa mereka tidak bisa berharap banyak dari usaha lain, karena disatu sisi usaha penangkapan ikan adalah salah satu kegiatan yang turun temurun dan merupakan pekerjaan pokok untuk memperoleh penghasilan dalam memenuhi kebutuhan hidup keluarga.

Sementara rata-rata pendapatan dari usaha menjadi buruh bangunan sebesar Rp 339.429/bulan (20,88\%), pendapatan dari usaha dagang yang diperoleh sekitar Rp 201.029 /bulan atau hanya memberikan kontribusi sebesar $12,36 \%$ dari total pendapatan rumah tangga nelayan. Walaupun pendapatan dari usaha dagang lebih rendah dari usaha penangkapan ikan dan menjadi buruh bangunan, namun saat ini usaha dagang masih merupakan mata pencaharian bagi istri nelayan di Kecamatan Batulayar dan merupakan penghasilan tambahan bagi rumah tangga nelayan. Kontribusi pendapatan juga didapat dari anggota rumah tangga (anak) yang bekerja sebagai karyawan yaitu sebesar Rp 34.286/bulan (2,11\%).

\section{Pendapatan per Kapita}

Pendapatan perkapita merupakanpendapatan yang dihitung dengan membagi total pendapatan rumah tangga dengan jumlah anggota rumah tangga nelayan, dimana diketahui bahwa jumlah anggota keluarga nelayan sebanyak 3 orang, disajikan pada Tabel 7 berikut.

Tabel 7. Pendapatan per Kapita Rumah Tangga Nelayan pada Tahun 2017

\begin{tabular}{|c|c|r|}
\hline Uraian & Perbulan & Per Kapita (3 orang) \\
\hline Pendapatan (Rp) & 1.625 .983 & 541.994 \\
\hline
\end{tabular}

Sumber : Data Primer Diolah, Tahun 2017

Berdasarkan Tabel 7 di atas dapat disimpulkan bahwa pendapatan rumah tangga perbulan di Kecamatan Batulayar sebesar Rp 1.625.983, dengan anggotan keluarga sebanyak 3 orang maka pendapatan per kapita per bulan sebesar nelayan adalah sebesar Rp 541.994, atau per harinya adalah sebesar Rp 18. 006

\section{Tingkat Kemiskinan Rumah Tangga Nelayan}

Daerah pesisir yang sebagian besar masyarakatnya memiliki pekerjaan utama sebagai nelayan sangat rentan dengan kondisi sosial ekonomi masyarakat terutama kemiskinan. Hal ini dikarenakan hasil laut yang didapat tidak menentu dan sangat ditentukan faktor cuaca serta musim.

Tingkat kemiskinan yang dimaksud dalam penelitian ini adalah besarnya tingkat kemiskinan masyarakat pesisir terutama rumah tangga nelayan di Kecamatan Batulayar. Kriteria yang digunakan adalah kriteria BPS dan Bank Dunia. Dimana berdasarkan kriteria kemiskinan menurut BPS (2017) rumah tangga nelayan dikatakan miskin apabila pendapatan perkapita/perbulan $\leq \mathrm{Rp} 401.220$. Hasil penelitian ini menunjukkan bahwa tingkat pendapatan per kapita per bulan di Kecamatan Batulayar 
sebesar Rp 541. 994, sehingga rumah tangga nelayan di Kecamatan Batulayar ini dikategorikan tidak miskin. Demikian pula jika menggunakan kriteria Bank Dunia maka rumah tangga nelayan juga dikategorikan tidak miskin, dimana menurut Bank Dunia masyarakat dikategorikan tidak miskin jika mempunyai penghasilan di atas US\$ 1 per kapita per hari. Dengan Kurs US\$ 1 sebesar Rp 13.500 (pada pertengahan tahun 2017), sedangkan hasil analisis menujukkan bahwa pendapatan per kapit per hari keluarga nelayan di Kecamatan Batu Layar Lombok Barat sebesar Rp 18.066.

\section{KESIMPULAN DAN SARAN}

\section{Kesimpulan}

1. Rata-rata pendapatan rumah tangga nelayan di Kecamatan Batulayar Kabupaten Lombok Barat Tahun 2016 sebesar 1.625.983/bulan, dengan rincian pendapatan dari usaha penangkapan ikan sebesar Rp 1.051.239/bulan, dan pendapatan dari luar usaha nelayan sebesar Rp 574.744.

2. Usaha penangkapan ikan memberikan kontribusi yang cukup tinggi terhadap total pendapatan rumah tangga nelayan. Kontribusi pendapatan dari usaha penangkapan ikan sebesar 64,65\%.

3. Rumah tangga nelayan di Kecamatan Batulayar Kabupaten Lombok Barat termasuk kategori tidak miskin baik berdasarkan Badan Pusat Statistik (2017) maupun kriteria Bank Dunia

\section{Saran}

Dalam upaya meningkatkan pendapatan dan kesejahteraan rumah tangga nelayan, diiharapkan kepada pemerintah atau instansi terkait untuk membuat kebijakan berupa program pemberdayaan usaha secara terpadu dengan menghasilkan berbagai produk olahan ikan (agroindustri perikanan) dan membantu penyediaan tempat berjualan.

\section{DAFTAR PUSTAKA}

Badan Pusat Statistik, 2015. Kecamatan Batulayar Dalam Angka. Badan Pusat Statistik Lombok Barat : Lombok Barat.

Dinas Perikanan dan Kelautan, 2014.Profil DKP Lombok Barat.Dinas Perikanan dan Kelautan Lombok Barat : Lombok Barat.

Soekartawi, 1988.Ilmu Usaha Tani dan Penelitian Untuk Pengembangan Petani Kecil. UL- Press. Jakarta

Susilowati, Indah, 1991, "Welfare Impact of Improved Boat Modernisation in Pemalang Regencies, Central Java, Indonesia", Master Thesis, The Faculty of Economics and Management, University Putra Malaysia Triana, N, 2015. Analisis Sosial Ekonomi Rumah Tangga Nelayan di Kecamatan Lembar Kabupaten Lombok Barat.Skripsi. Fakultas Pertanian Universitas Mataram: Mataram. 